\title{
TOMOGRAPHIC STUDY OF THE S2-ALAR-ILIAC SCREW TECHNIQUE IN BRAZILIAN MEN
}

\author{
ESTUDO TOMOGRÁFICO DA TÉCNICA DO PARAFUSO DE S2-ALAR-ILÍACO \\ EM HOMENS BRASILEIROS \\ ESTUDIO TOMOGRÁFICO DE LA TÉCNICA DEL TORNILLO S2-ALAR-ILÍACO \\ EN HOMBRES BRASILENNOS
}

\author{
Luis Pimentel Sombra, ${ }^{1}$ Ricardo Teixeira e Silva, ${ }^{1}$ Thiego Pedro Freitas Araújo, ${ }^{1}$ Olavo letalf BiraghI, ${ }^{1}$ Raphael Martus Marcon, ${ }^{1}$ Alexandre Fogaça Cristante, ${ }^{1}$ \\ Tarcísio Eloy Pessoa de Barros Fllho \\ 1. Universidade de São Paulo, Faculdade de Medicina, Hospital das Clínicas, Instituto de Ortopedia e Traumatologia, Spine Department, São Paulo, SP, Brazil.
}

\begin{abstract}
Objective: The use of pedicle screws was a milestone for modern spinal surgery. This type of fixation, due to its superior biomechanics, gave greater fixation power, greater capacity to withstand the pulling forces and, therefore, greater stability and lower rates of pseudoarthrosis. Fixation of the lumbosacral junction, even with the development of these new implants, remains a challenge mainly because the considerable rates of pseudoarthrosis. The use of iliac screws solves the biomechanical difficulties. However, its use shows high rates of surgical wound problems. The S2-Alar-lliac screw (S2Al) came as a solution to these complications. The lack of studies about anatomical and anthropometric parameters in the Brazilian population justifies the study. Methods: Eleven hip tomographies of Brazilian adult males were analyzed by four evaluators. The right and left sides were considered. In each patient, measurements were made of greater and shorter bone length, greater and smaller bone diameter, distance from the entry point to the skin, sagittal and axial angles related to the hypothetical insertion of an S2Al screw and compared to the same measurements obtained with the iliac screw. Results: The mean bone length was $136.7 \mathrm{~mm}$, the greatest bone diameter was $24.8 \mathrm{~mm}$, the smallest bone diameter was $19.7 \mathrm{~mm}$ and the distance from the screw to the skin was $42.1 \mathrm{~mm}$ for the S2Al screw. Conclusions: The obtained data present an average of the sample that can be useful in the decision of the surgical technique in the studied group. Level of evidence I; Diagnostic Studies (Anatomical Investigation).
\end{abstract}

Keywords: Anatomy; Lumbosacral Region; Spinal Diseases.

\section{RESUMO}

Objetivo: O uso de parafusos pediculares foi um marco para a cirurgia moderna de coluna vertebral. Esse tipo de fixação, devido a sua biomecânica superior, deu maior poder de fixação, maior capacidade de resistir às forças de arrancamento e, portanto, maior estabilidade e menores taxas de pseudoartrose. A fixação da junção lombossacra, mesmo com o desenvolvimento destes novos implantes, permanece um desafio devido, principalmente, às consideráveis taxas de pseudoartrose. O uso de parafusos de ilíaco resolve o problema biomecânico. Entretanto, seu uso mostra elevadas taxas de problemas na ferida operatória. O parafuso de S2-Alar-llíaco (S2Al) veio como solução para essas complicações. A falta de estudos acerca dos parâmetros anatômicos e antropométricos na população brasileira justifica o estudo realizado. Métodos: Foram analisadas 11 tomografias de bacia de homens brasileiros adultos por 4 avaliadores. Foram considerados os lados direito e esquerdo. Em cada paciente foram feitas medidas de maior e menor comprimento ósseo, maior e menor diâmetro ósseo, distância do ponto de entrada na pele, ângulos sagital e axial relacionadas à hipotética inserção de um parafuso S2Al e comparadas às mesmas medidas obtidas em relação ao parafuso de ilíaco. Resultados: O comprimento ósseo médio foi de 136,7 mm, maior diâmetro ósseo foi de 24,8 mm, o menor diâmetro ósseo de 19,7 mm e a distância do parafuso para a pele foi de $42,1 \mathrm{~mm}$ para o parafuso S2Al. Conclusão: Os dados obtidos apresentam uma média da amostra que podem ser úteis na decisão da técnica cirúrgica no grupo estudado. Nível de evidência I; Estudo Diagnóstico (Investigação Anatômica).

Descritores: Anatomia; Região Lombossacral; Doenças da Coluna Vertebral.

\section{RESUMEN}

Objetivo: El uso de tornillos pediculares fue un marco para la cirugía moderna de la columna vertebral. Este tipo de fijación, debido a su biomecánica superior, dio mayor poder de fijación, mayor capacidad de resistir a las fuerzas de tracción y, por lo tanto, mayor estabilidad y menores tasas de pseudoartrosis. La fijación de la unión lumbosacra, incluso con el desarrollo de estos nuevos implantes, sigue siendo un desafío debido principalmente a las considerables tasas de pseudoartrosis. El uso de tornillos ilíacos soluciona el problema biomecánico. Sin embargo, su uso muestra altas tasas de problemas en la herida quirúrgica. El tornillo S2-Alar-llíaco (S2Al) vino como solución para estas complicaciones. La falta de estudios sobre los parámetros anatómicos y antropométricos en la población brasileña justifica el estudio realizado. Métodos: Se analizaron 11 tomografías de cadera de hombres brasileños adultos por 4 evaluadores, considerando los lados derecho e izquierdo. En cada paciente se realizaron medidas de mayor y menor longitud ósea, mayor y menor diámetro óseo, distancia del punto de entrada en la piel, ángulos sagital y axial relacionados con la inserción hipotética de un tornillo S2Al y comparados a las mismas medidas obtenidas en relación al tornillo ilíaco. Resultados: La longitud ósea promedio fue de 136,7 mm, el mayor diámetro óseo fue de 24,8 mm, el diámetro óseo menor de 19,7 mm y la distancia del tornillo a la piel fue de $42,1 \mathrm{~mm}$ para el tornillo S2Al. Conclusiones: Los datos obtenidos presentan un promedio de la muestra que puede ser útil en la decisión de la técnica quirúrgica en el grupo estudiado. Nivel de evidencia I; Estudios de Diagnósticos (Investigación Anatómica).

Descriptores: Anatomía; Región Lumbosacra; Enfermedades de la Columna Vertebral. 


\section{INTRODUCTION}

In spite of the continuous development of new implants and new fixation techniques, arthrodesis of the lumbosacral junction continues to be a challenge in both the adult and pediatric populations. ${ }^{1}$

The biomechanical forces acting in this region frequently lead to problems of non-union and loss of fixation.

There are several indications for the use of lumbosacral fixation. The most common is distal fixation in long posterior constructions in patients undergoing surgery for adult deformities. Other commonly reported indications include high-grade spondylolisthesis, unstable sacral fractures, sacral tumors, sacral insufficiency fractures, three column osteotomies close to the lumbosacral junction, and cases of poor sacral fixation or a high risk of pseudoarthrosis in L5-S1.2

Historically, several possibilities have been described for fixation of this region, such as Galveston rods, ${ }^{3}$ and S1, S2, S2-alar, and iliac pedicle screws. ${ }^{4}$

Starting in the 1990s, with a better understanding of the function of mechanical forces in the region, the use of iliac screws became popular in procedures that required more distal fixation as a way to reduce construction failure rates. ${ }^{2,5,6}$ However, although it was an effective technique in fixations of the lumbosacral junction, the use of iliac screws was a significant source of complications, such as prominence of the synthesis material, exposure of the material, infections, and loosening, which led many patients to new procedures with worse clinical outcomes. Thin or low-weight patients were particularly affected by these complications, since the lesser amount of subcutaneous cellular tissue led to a higher susceptibility to developing coverage problems with these types of screws.

Thus, as an alternative to the use of iliac screws, the S2-alar-iliac screw technique was developed. By using a more medial starting point than with traditional iliac screws, the need for offset connectors was eliminated, which improved the profile of the implant construction, limiting soft tissue dissection, and avoiding the typical skin complications of the iliac screws. ${ }^{7-10}$

The original description of the technique was made in an American pediatric and adult population. ${ }^{9,10}$ There is also a description in Asian populations. The studies describe a population comprised of $50 \%$ males and $50 \%$ females and demonstrate little difference between the sexes. ${ }^{11-13}$ However, others showed that there are indeed anatomical differences between the sexes and between populations, ${ }^{14-17}$ which justifies the development of studies in different populations in order to analyze the average anatomical parameters of each population group.

In view of the above, as well as of the lack of national studies on the topic, we saw the need to develop a study focused on the Brazilian population and its subgroup defined by sex, age range, comorbidities, and others, The objective of this study is to show the radiographical parameters for passage of the S2Al screw in a population of Brazilian men and compare them with the same parameters of the iliac screw.

\section{METHODS}

After approval by the Institutional Review Board as protocol number 1.726.509, we conducted a retrospective analysis of normal pelvic computed tomographies performed electively for the investigation of intra-abdominal pathologies. All the tomographies had to have three-dimensional axial, coronal, and sagittal cuts. The examinations of 25 patients between the ages of 18 and 65 years were selected from the year 2016 randomly, in non-consecutive form. Of the total 25 patients, 14 were women and were excluded from the study. None of the selected patients had bone deformities of the lumbosacral spine or pelvis.

The examinations were analyzed by Isite (Phillips) ${ }^{\circledR}$ from three-dimensional reconstructions of the computed tomographies by two Orthopedics and Traumatology residents and two spine surgery fellows. All measurements were taken bilaterally.

The data were standardized as follows: age in years; screw diameter, length, and width measured in millimeters; and angles measured in degrees. The measurements of the S2Al screw parameters were taken as follows:

- Length: distance between the point of insertion of the S2Al screw (between S1 and S2, $2 \mathrm{~mm}$ lateral to the paramedian sacral crest) and the anterior inferior iliac spine. (Figure 1)

- Sagittal angle: angle of inclination of the S2AI screw in the sagittal CT cut. (Figure 2)

- Axial angle: angle of inclination of the S2Al screw in the axial cut of the CT. (Figure 3)

- Greatest diameter: greatest diameter between the external and internal cortical parts of the iliac bone.

- Smallest diameter: smallest diameter between the external and internal iliac cortices in their isthmic region.

- Distance from the skin: distance between the point of insertion of the S2Al screw and the skin.

\section{RESULTS}

The variables evaluated were presented in tables with absolute and relative frequency distribution. The statistical significance of the differences of the means of the quantitative variables was verified

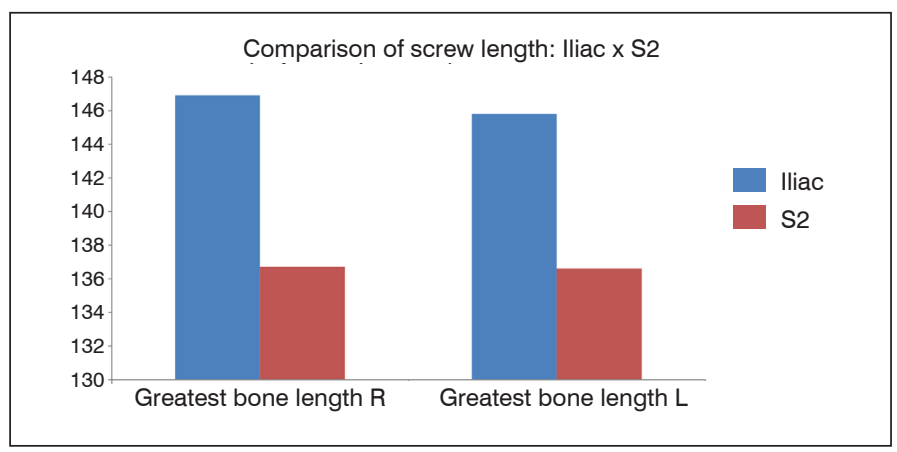

Figure 1. Comparison of screw lengths.

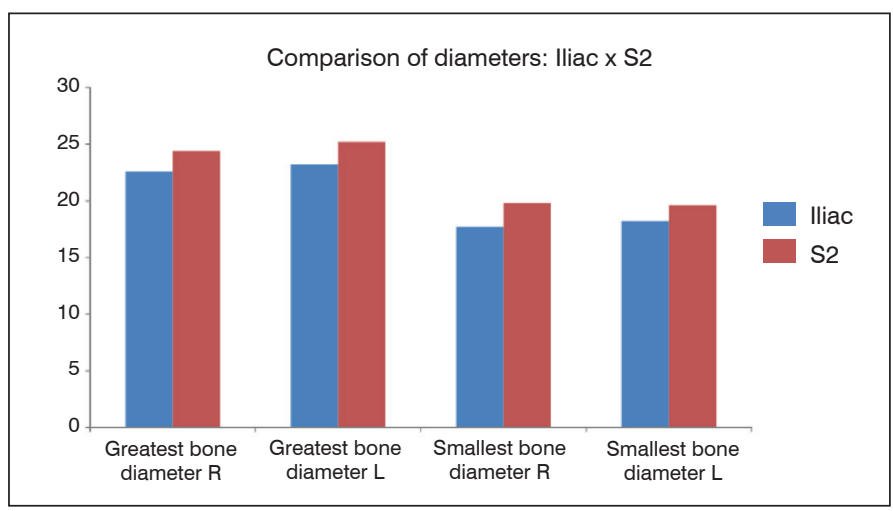

Figure 2. Comparison of screw diameters.

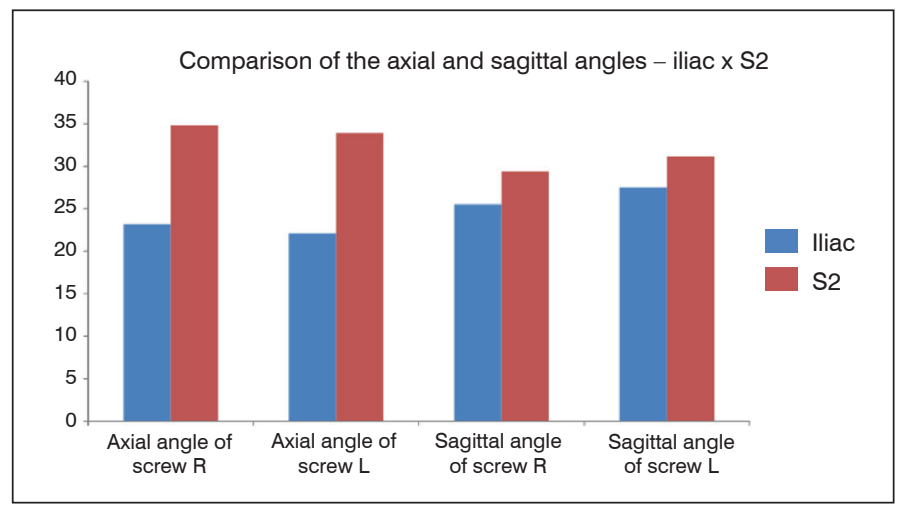

Figure 3. Comparison between the axial and sagittal angles. 
using the non-paired Student's t-test. All analyses were performed with a significance level of $5 \%$, and therefore, results with p-values less tham 0.05 were considered statistically significant, alwayss taking alternative two-tailed hypotheses into account.

The information collected was used to populate a database developed in Excel ${ }^{\circledR}$ for Windows and the statistical analysis was performed using STATA ${ }^{\circledR} 11$ SE software.

The study was comprised of 11 patients with a mean age of 49 years (standard deviation of 12.3), ranging from 19 to 63 years of age. All patients (100\%) were male.

\section{Iliac}

The mean value, considering all observers, of the greatest bone length was $146.9 \mathrm{~mm}$ (right side) and $145.8 \mathrm{~mm}$ (left side). The mean greatest diameter was $22.6 \mathrm{~mm}$ and $23.2 \mathrm{~mm}$, right and left sides respectively, while the mean smallest diameter was $17.7 \mathrm{~mm}$ on the right side and $18.2 \mathrm{~mm}$ on the left side, as presented in Table 1.

As regards angles, the mean axial angle of the screw was $23.2^{\circ}$ on the right side and $22.1^{\circ}$ on the left side. The mean sagittal angle was $25.5^{\circ}$ and $27.5^{\circ}$, on the right and left sides, respectively. The distance from the skin was $21.9 \mathrm{~mm}$ on the right side and $21.4 \mathrm{~mm}$ on the left side.

\section{S2}

Table 2 presents the S2 screw values obtained through tomography. Figure 4 illustrates how the length of the screw was measured. The mean greatest bone length measured was $136.7 \mathrm{~mm}$ on the right side and $136.6 \mathrm{~mm}$ on the left side. In terms of diameter, the greatest bone diameter was $24.4 \mathrm{~mm}$ on the right and $25.2 \mathrm{~mm}$ on the left. The smallest bone diameter had mean values of $19.8 \mathrm{~mm}$ (right) and 19.6mm (left)

As regards the angles, as illustrated in Figures 5 and 6, the axial angle measured $34.8^{\circ}$ on the right side and 33.9 on the left side, while the mean sagittal angle measured $34.8^{\circ}$ and $33.9^{\circ}$, on the right and left sides, respectively.

Table 3 shows the comparison between the iliac and S2 screw measurements. In these comparisons, it can be observed that the mean length of the iliac screw is greater, but the diameters, angles, and distance from the skin are smaller.

The comparisons between the measurements in the two groups can be seen in schematic form in the graphs below.

\section{DISCUSSION}

Fixation of the lumbosacral junction is a widely accepted technique for a variety of indications - deformities, degenerative diseases, and tumors, among others. The classic technique using iliac screws has been shown to be biomechanically stable and capable of resisting the intense forces present at this location, significantly reducing the occurrence of pseudoarthrosis and material failure. However, this technique is often associated with problems, such as the need for more extensive dissection to connect the screws to the rod, the use of offset connectors, and a higher rate of complications of the surgical wound.5,6,18 These data are corroborated by the results of our study, which showed that iliac screws have a distance from the

Table 1. lliac screw values.

\begin{tabular}{|c|c|c|c|c|c|c|c|c|c|c|c|c|}
\hline \multirow[t]{2}{*}{ Patient } & \multicolumn{2}{|c|}{ Greatest bone length } & \multicolumn{2}{|c|}{$\begin{array}{c}\text { Greatest bone } \\
\text { diameter }\end{array}$} & \multicolumn{2}{|c|}{$\begin{array}{c}\text { Smallest bone } \\
\text { diameter }\end{array}$} & \multicolumn{2}{|c|}{$\begin{array}{l}\text { Axial angle of the } \\
\text { screw }\end{array}$} & \multicolumn{2}{|c|}{$\begin{array}{c}\text { Sagittal angle of the } \\
\text { screw }\end{array}$} & \multicolumn{2}{|c|}{ Distance from skin } \\
\hline & $\mathbf{R}$ & $\mathbf{L}$ & $\mathbf{R}$ & $\mathbf{L}$ & $\mathbf{R}$ & $\mathbf{L}$ & $\mathbf{R}$ & $\mathrm{L}$ & $\mathbf{R}$ & $\mathrm{L}$ & $\mathbf{R}$ & $\mathrm{L}$ \\
\hline 1 & 154.3 & 156.0 & 24.5 & 26.4 & 17.4 & 19.2 & 20.9 & 21.1 & 26.1 & 28.2 & 10.7 & 13.4 \\
\hline 2 & 132.3 & 129.6 & 20.4 & 19.8 & 16.8 & 17.1 & 26.6 & 22.5 & 30.2 & 28.1 & 27.0 & 26.1 \\
\hline 3 & 147.1 & 145.6 & 22.8 & 23.4 & 17.7 & 19.1 & 19.9 & 22.8 & 24.0 & 27.5 & 28.1 & 25.8 \\
\hline 4 & 158.8 & 159.0 & 22.3 & 22.6 & 17.8 & 17.5 & 23.3 & 23.4 & 29.5 & 32.7 & 11.2 & 10.6 \\
\hline 5 & 147.0 & 143.1 & 20.0 & 20.5 & 16.9 & 16.4 & 23.5 & 25.2 & 27.5 & 27.8 & 11.8 & 12.4 \\
\hline 6 & 136.9 & 138.6 & 24.4 & 24.9 & 20.4 & 21.3 & 25.6 & 23.3 & 26.0 & 28.3 & 34.9 & 32.3 \\
\hline 7 & 147.8 & 149.8 & 24.5 & 24.8 & 18.9 & 18.2 & 22.0 & 21.7 & 23.2 & 25.9 & 28.8 & 26.3 \\
\hline 8 & 150.3 & 147.7 & 20.6 & 22.0 & 16.4 & 18.5 & 21.4 & 20.7 & 22.6 & 26.2 & 28.3 & 27.8 \\
\hline 9 & 146.4 & 144.1 & 25.7 & 25.5 & 19.9 & 20.3 & 25.4 & 19.2 & 24.1 & 26.5 & 23.7 & 22.0 \\
\hline 10 & 145.0 & 141.6 & 21.9 & 21.3 & 17.5 & 16.5 & 23.6 & 22.2 & 26.9 & 28.3 & 21.3 & 21.8 \\
\hline 11 & 150.2 & 148.9 & 21.9 & 23.7 & 14.6 & 16.8 & 22.9 & 21.1 & 20.5 & 22.7 & 15.2 & 17.2 \\
\hline $\begin{array}{l}\text { Mean by } \\
\text { side }\end{array}$ & 146.9 & 145.8 & 22.6 & 23.2 & 17.7 & 18.2 & 23.2 & 22.1 & 25.5 & 27.5 & 21.9 & 21.4 \\
\hline Final mean & \multicolumn{2}{|c|}{146.3} & \multicolumn{2}{|c|}{22.9} & \multicolumn{2}{|c|}{18.0} & \multicolumn{2}{|c|}{22.6} & \multicolumn{2}{|c|}{26.5} & \multicolumn{2}{|c|}{21.7} \\
\hline
\end{tabular}

Table 2. S2Al screw values

\begin{tabular}{|c|c|c|c|c|c|c|c|c|c|c|c|c|}
\hline Patient & \multicolumn{2}{|c|}{ Greatest bone length } & \multicolumn{2}{|c|}{$\begin{array}{c}\text { Greatest bone } \\
\text { diameter }\end{array}$} & \multicolumn{2}{|c|}{$\begin{array}{c}\text { Smallest bone } \\
\text { diameter }\end{array}$} & \multicolumn{2}{|c|}{$\begin{array}{c}\text { Axial angle of the } \\
\text { screw }\end{array}$} & \multicolumn{2}{|c|}{$\begin{array}{c}\text { Sagittal angle of the } \\
\text { screw }\end{array}$} & \multicolumn{2}{|c|}{ Distance from skin } \\
\hline 1 & 158.6 & 157.4 & 26.5 & 27.0 & 21.3 & 20.8 & 29.2 & 29.6 & 28.2 & 29.9 & 23.3 & 22.9 \\
\hline 3 & 136.3 & 135.4 & 24.6 & 23.6 & 20.3 & 19.3 & 33.0 & 35.1 & 27.0 & 28.4 & 44.3 & 42.6 \\
\hline 4 & 147.1 & 149.0 & 24.6 & 26.3 & 20.4 & 20.9 & 37.5 & 37.9 & 26.4 & 28.9 & 36.7 & 28.6 \\
\hline 5 & 136.1 & 132.8 & 23.3 & 23.9 & 19.6 & 19.5 & 36.1 & 36.7 & 29.4 & 34.1 & 28.8 & 31.1 \\
\hline 8 & 135.9 & 133.6 & 22.0 & 24.4 & 17.9 & 17.6 & 36.7 & 35.3 & 29.0 & 33.6 & 55.9 & 56.9 \\
\hline 9 & 138.9 & 140.6 & 24.4 & 28.8 & 20.5 & 20.5 & 35.4 & 29.9 & 33.2 & 29.3 & 35.9 & 33.0 \\
\hline 10 & 129.3 & 129.0 & 22.9 & 22.0 & 18.9 & 18.6 & 35.1 & 35.5 & 27.6 & 31.3 & 39.3 & 40.6 \\
\hline 11 & 139.2 & 139.0 & 23.9 & 23.2 & 17.6 & 17.6 & 34.3 & 32.3 & 28.1 & 31.8 & 33.4 & 37.2 \\
\hline $\begin{array}{l}\text { Mean by } \\
\text { side }\end{array}$ & 136.7 & 136.6 & 24.4 & 25.2 & 19.8 & 19.6 & 34.8 & 33.9 & 29.4 & 31.1 & 42.2 & 42.1 \\
\hline
\end{tabular}




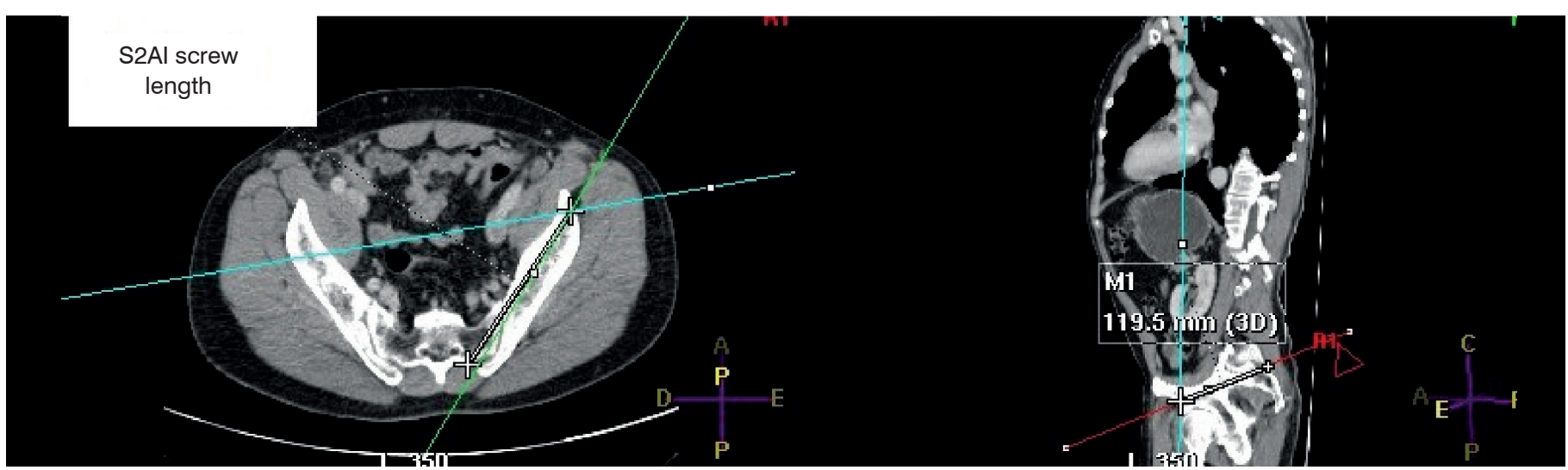

Figure 4. Length of the S2Al screw.

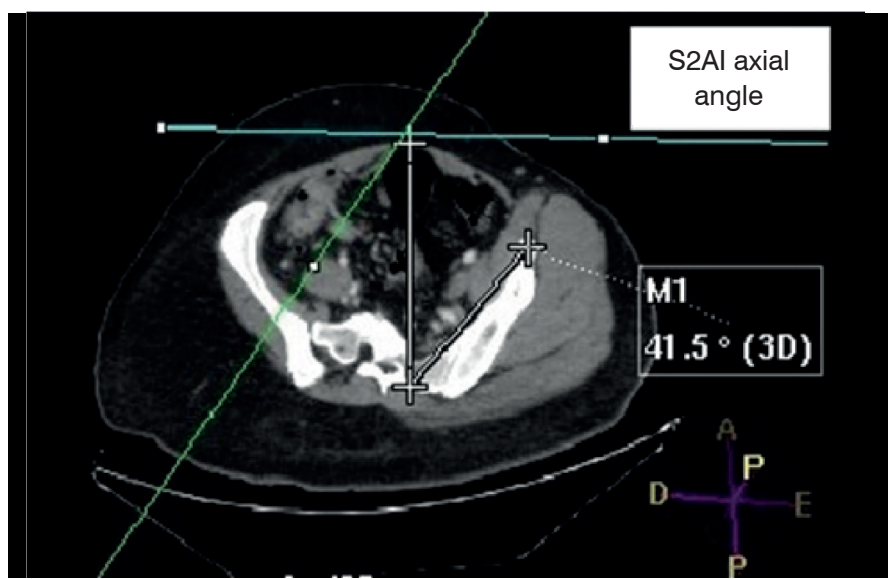

Figure 5. Axial angle of the S2Al screw.

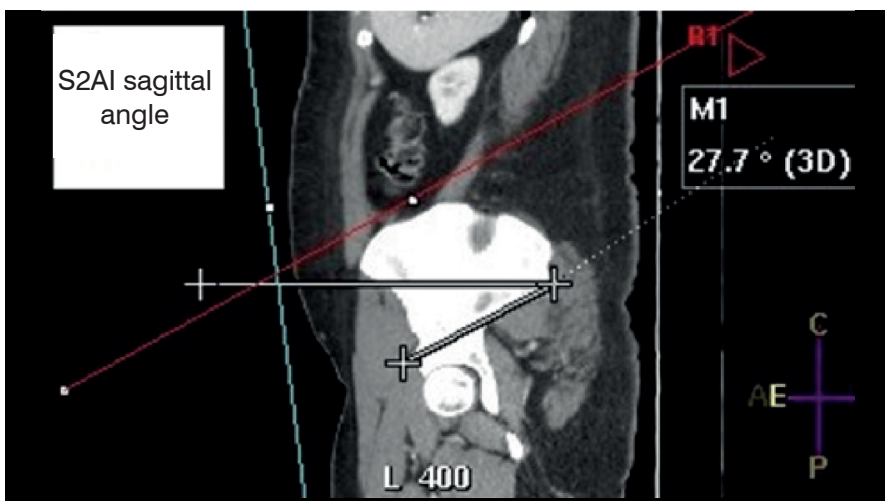

Figure 6. Sagittal angle of the S2Al screw.

Table 3. Data comparison between iliac screw and S2AI screw.

\begin{tabular}{c|c|c|c|c|c}
\hline \multirow{2}{*}{ Variable } & \multicolumn{2}{|c|}{ Iliac } & \multicolumn{2}{c|}{ S2 } & \multirow{2}{*}{ p } \\
\cline { 2 - 5 } & Mean & SD & Mean & SD & \\
\hline Greatest bone length R & 146.9 & 2.7 & 136.7 & 2.7 & 0.02 \\
\hline Greatest bone length L & 145.8 & 2.2 & 136.6 & 2.4 & 0.03 \\
\hline Greatest bone diameter R & 22.6 & 2.1 & 24.4 & 1.7 & 0.02 \\
\hline Greatest bone diameter L & 23.2 & 2.1 & 25.2 & 1.7 & 0.03 \\
\hline Smallest bone diameter R & 17.7 & 2.1 & 19.8 & 1.6 & 0.002 \\
\hline Smallest bone diameter L & 18.2 & 2.8 & 19.6 & 2.1 & 0.04 \\
\hline Axial angle of screw R & 23.2 & 1.3 & 34.8 & 1.8 & $<0.001$ \\
\hline Axial angle of screw L & 22.1 & 1.9 & 33.9 & 1.9 & $<0.001$ \\
\hline Sagittal angle of screw R & 25.5 & 2.2 & 29.4 & 3.3 & 0.004 \\
\hline Sagittal angle of screw L & 27.5 & 3 & 31.1 & 4.4 & 0.001 \\
\hline Distance between skin and & & & & & \\
screw R & 21.9 & 3.4 & 42.2 & 2.4 & $<0.001$ \\
\hline Distance between skin and & & & & & \\
screw L & 21.4 & 3.8 & 42.1 & 4.5 & $<0.001$ \\
\hline
\end{tabular}

skin of about half the distance of S2AI screws, which leads to a higher risk of skin complications like dehiscence and prominence.

The development of the fixation technique described by Kebaish ${ }^{9}$ and Sponseller, ${ }^{10}$ the S2Al, was aimed at minimizing the high risk of hardware complications in iliac fixation systems, widely used up to that time.

Several studies of fixations with these two types of screws observed similarities in resistance to the diverse forces between the two fixation techniques for this region, ${ }^{1,8,19}$, but constructions that use S2AI have the advantage of lower hardware complication rates.

The technique described by Sponseller ${ }^{6}$ defines the point of entry as being approximately $25 \mathrm{~mm}$ caudal to the upper terminal plate of $\mathrm{S} 1$ and $22 \mathrm{~mm}$ lateral to the midline, angled $40^{\circ}$ laterally and caudally. His contemporary described the same technique ${ }^{5}$ as being 2 to $4 \mathrm{~mm}$ lateral to and 4 to $8 \mathrm{~mm}$ distal to the distal sacral foramen of S1.

The literature reports parameters slightly different than those presented in the original descriptions, which allows multiple study designs to be conducted. Our study used a point of entry with the midline between S1 and S2 and a point $2 \mathrm{~mm}$ lateral to the foramen in the direction towards the anterior-inferior iliac spine as references. ${ }^{12}$ The choice of this point was a way to use easily locatable anatomical parameters that could be used intraoperatively and that would reduce surgical time and use of the radioscope to locate the point of entry.

There are not many studies that evaluate the anatomical pelvic parameters associated with the placement of this type of implant in either general or specific populations. The pioneering studies were conducted in the American population and subsequently evaluations in Asian populations emerged..$^{11-13}$ The Brazilian population and its subgroups are not contemplated by these analyses, although they generate an extensive and highly useful field for national spine surgery research.

Studies that permit the study of anatomical parameters in the Brazilian population are potentially useful because they allow us to determine the best points of entry, pathways, angulations, types and sizes of implants to be used, which could impact surgical planning and material companies

Studies of American cadavers have shown that screws that are $7.5 \mathrm{~mm}$ thick and between 70 and $100 \mathrm{~mm}$ long can be inserted without high risk of violation of the bony wall of the path, ${ }^{20,21}$ measurements well below those reported in our study. The data obtained can guide the surgeons who work with the study population group to use longer and thicker screws safely.

A study by Kwan et al. ${ }^{12}$ that analyzed the path of the S2Al in the Asian population (Chinese, Malay, and Indian) showed a variation in screw length of from 122.6 to 85.3 in men. The axial angulation varied from 39.3 to 50.4 degrees, depending on the greater or lesser path of the screw. In our study the mean greatest screw length was $24.8 \mathrm{~mm}$ and the mean axial and sagittal angulations were 34.3 and 30.2 degrees, respectively.

The differences between the data from our study and the rest of the literature are probably due to the differences between the 
population groups studied. This study was based on adult Brazilian men and this is probably the cause of the variations in results, given that other studies have shown that ethnic and gender differences can modify the study parameters. ${ }^{11}$

Our study demonstrated the possibility of using S2Al screws safely in the study group, both with implants already in use today and with possibly larger and thicker implants, as well as suggesting a safe path that is easy to locate during surgery.

The major limitation of the study is the small number of patients evaluated. However, the results obtained, even with the small sample, indicate that the male Brazilian population has parameter values different from those of the American population, which should be explored in future studies with larger samples and studies in specific groups in order to obtain a profile of the Brazilian population as a whole.

Another point to be highlighted is that different programs used for the analysis of CT scans may lead to differences in measurements, such as the magnification of the examination. The non-inclusion of patient weight and height is another flaw in data interpretation, since it does not allow us to suitably pair the size of the measurements with the size of the subject evaluated.

Thus, it can be seen that this topic can generate various new nationally relevant studies in the future.

\section{CONCLUSION}

Based on research data, we conclude that the S2Al screw can be used as an alternative to the conventional iliac screw in the study population. The information published in this study, given the appropriate weighting, will probably assist spine surgeons in the choice of the best implant and in the screw insertion technique for lumbopelvic fixations.

All authors declare no potential conflict of interest related to this article.

CONTRIBUTION OF THE AUTHORS: Each author made significant individual contributions to this manuscript. LPS (0000-0003-1598-1094)* RTS $(0000-0003-4405-373 X)^{\star}$, and TPFA (0000-0002-8670-1793)* were the main contributors to the concept and design of the study, data acquisition, and writing of the manuscript. OLB (0000-0002-2614-1771)* contributed to the study design, the evaluation and discussion of the data and the results obtained, and the writing of the manuscript. RMM (0000-0001-5958-5646)*. AFC (0000-0002-7797-5274)*, and TEPBF (0000-0002-7969-7845)* reviewed the manuscript and contributed to the intellectual concept of the study, in addition to approving the final version. * ORCID (Open Researcher and Contributor ID).

\section{REFERENCES}

1. Hoernschemeyer DG, Paschuck TD, Pfeiffer FM. Analysis of the s2 alar-iliac screw as compared with the traditional iliac screw: does it increase stability with sacroiliac fixation of the spine? Spine J. 2017;17(6):875-9.

2. McNeill IT, Rothrock RJ, Cho SK, Caridi JM. Pelvic fixation techniques and impacton sagittal balance: A literature review. Semin Spine Surg. 2017;29(4):184-91.

3. Peelle MW, Lenke LG, Bridwell KH, Sides B. Comparison of pelvic fixation techniques in neuromuscular spinal deformity correction: Galveston rod versus iliac and lumbosacral screws. Spine (Phila Pa 1976). 2006;31(20):2392-8; discussion 2399.

4. Miladi LT, Ghanem IB, Draoui MM, Zeller RD, Dubousset JF. lliosacral screw fixation for pelvic obliquity in neuromuscular scoliosis: A long-term follow-up study. Spine (Phila Pa 1976). 1997:22(15):1722-9.

5. Emami A. Deviren V. Berven S, Smith JA. Hu SS, Bradford DS. Outcome and complications of long fusions to the sacrum in adult spine deformity: luque-galveston, combined iliac and sacral screws, and sacral fixation. Spine (Phila Pa 1976). 2002;27(7):776-86.

6. Tsuchiya K, Bridwell KH, Kuklo TR, Lenke LG, Baldus C. Minimum 5-year analysis of L5-S1 fusion using sacropelvic fixation (bilateral S1 and iliac screws) for spinal deformity. Spine (Phila Pa 1976). 2006:31(3):303-8

7. Smith EJ, Kyhos J, Dolitsky R, Yu W, O 'Brien J. S2 Alar lliac Fixation in Long Segment Constructs, a Two- to Five-Year Follow-up. Spine Deform. 2018:6(1):72-8.

8. Ishida W, Elder BD, Holmes C, Goodwin CR, Lo SL, Kosztowski TA, et al. S2-Alar-lliac Screws are Associated with Lower Rate of Symptomatic Screw Prominence than Iliac Screws: Radiographic Analysis of Minimal Distance from Screw Head to Skin. World Neurosurg. 2016;93:253-60.

9. Kebaish KM. Sacropelvic fixation: techniques and complications. Spine (Phila Pa 1976). 2010;35(25):2245-51

10. Sponseller PD. Innovative Techniques in Pediatric Deformity: Use of Temporary Interna Distraction and the Sacral Alar lliac Technique in the Pediatric Population. Semin Spine Surg. 2012;24(3):180-5
11. Zhu F, Bao HD, Yuan S, Wang B, Qiao J, Zhu ZZ, et al. Posterior second sacral alar iliac screw insertion: Anatomic study in a Chinese population. Eur Spine J. 2013:22(7):1683-9.

12. Kwan MK, Jeffry A, Chan CYW, Saw LB. A radiological evaluation of the morphometry and safety of S1, S2 and S2-ilium screws in the Asian population using three dimensional computed tomography scan: An analysis of 180 pelvis. Surg Radiol Anat. 2012;34(3):217-27

13. Chang TL, Sponseller PD, Kebaish KM, Fishman EK. Low profile pelvic fixation: anatomic parameters for sacral alar-iliac fixation versus traditional iliac fixation. Spine (Phila Pa 1976) 2009:34(5):436-40

14. Fischer B, Mitteroecker P. Allometry and Sexual Dimorphism in the Human Pelvis. Anat Rec (Hoboken). 2017;300(4):698-705.

15. Kurki HK. Bilateral Asymmetry in the Human Pelvis. Anat Rec (Hoboken). 2017;300(4):653-65.

16. Mallard AM, Savell KRR, Auerbach BM. Morphological Integration of the Human Pelvis with Respect to Age and Sex. Anat Rec (Hoboken). 2017;300(4):666-74.

17. Handa VL, Lockhart ME, Fielding JR, Catherine S, Brubakery L, Cundiffy GW, et al. NIH Public Access. Victoria 2008;111:914-20.

18. Kuklo TR, Bridwell KH, Lewis SJ, Baldus C, Blanke K, Iffrig TM, et al. Minimum 2-year analysis of sacropelvic fixation and L5-S1 fusion using S1 and iliac screws. Spine (Phila Pa 1976). $2001 ; 26(18): 1976-83$.

19. Burns CB, Dua K, Trasolini NA, Komatsu DE, Barsi JM. Biomechanical Comparison of Spinopelvic Fixation Constructs: Iliac Screw Versus S2-Alar-lliac Screw. Spine Deform. 2016;4(1):10-5.

20. Matteini LE, Kebaish KM, Volk WR, Bergin PF, Yu WD, O'Brien JR. An S-2 alar iliac pelvic fixation. Technical note. Neurosurg Focus. 2010;28(3):E13

21. O'Brien JR, Yu WD, Bhatnagar R, Sponseller P, Kebaish KM. An anatomic study of the S2 iliac technique for lumbopelvic screw placement. Spine (Phila Pa 1976). 2009;34(12):E439-42. 